\title{
Can differences in heat flow between east and southern Africa be easily interpreted?: Implications for understanding regional variability in continental heat flow
}

\author{
Andrew A. Nyblade and Henry N. Pollack \\ Department of Geological Sciences, University of Michigan, Ann Arbor, MI 48019, USA
}

(Received November 28, 1992; revised version accepted July 8, 1992)

\begin{abstract}
Nyblade, A.A. and Yollack, H.N., 1993. Can differences in heat flow between east and southern Africa be easily interpreted?: Implications for understanding regional variability in continental heat flow. Tectonophysics, 219: 257-272.

We address the extent to which regional variations in continental heat flow can be interpreted, making use of a heat flow data set from east and southern Africa. The first-order observation deriving from these heat flow measurements is a common pattern characterized in both regions by low heat flow in Archean cratons and higher heat flow in younger mobile belts. Two regional differences between east and southern Africa are superimposed on this common heat flow pattern: (1) heat flow in the Tanzania Craton is about $13 \mathrm{~mW} \mathrm{~m}^{-2}$ lower than in the Kalahari Craton, and (2) heat flow in the Mozambique Belt in east Africa is about $9 \mathrm{~mW} \mathrm{~m}^{-2}$ lower than in the southern African mobile belts, within about $250 \mathrm{~km}$ of the respective Archean cratons. The differences in heat flow between east and southern Africa suggest that the thermal structure of the lithosphere beneath these regions differs somewhat, and we attempt to resolve these differences in lithospheric thermal structure by examining four explanations that could account for the heat flow observations: (1) diminished heat flow in shallow boreholes in east Africa; (2) less crustal heat production in the regions of lower heat flow; (3) thicker lithosphere beneath the regions of lower heat flow; (4) cooler mantle beneath the areas of lower heat flow. We find it difficult to interpret uniquely the heat flow differences between east and southern Africa because available constraints on crustal heat production, crustal structure, lithospheric thickness and mantle temperatures are insufficient to discriminate among the possible explanations. Hence, extracting significant information about lithospheric thermal structure from regional heat flow variations requires more ancillary geochemical and geophysical information than Africa presently offers.
\end{abstract}

\section{Introduction}

Since the first heat flow measurements were made five decades ago (Benfield, 1939; Bullard, 1939) more than 20,000 additional measurements have accumulated (Pollack et al., 1990). These data have refined the estimate of the Earth's mean heat loss and given insight into first-order variation in oceanic and continental heat flow. On the continents, significant advances in under-

Correspondence to: A.A. Nyblade, Department of Geosciences, Penn State University, Deike Building, University Park, PA 16802, USA. standing include (1) the recognition that heat flow varies with tectonic age and lithospheric thickness (Kraskovski, 1961; Lee and Uyeda, 1965; Polyak and Smirnov, 1968; Sclater and Francheteau, 1970; Chapman and Furlong, 1977; Sclater et al., 1980; Morgan, 1984; Ballard and Pollack, 1987; Nyblade and Pollack, 1993), and (2) recognition of the linear relationship between surface heat flow and crustal heat production (Roy et al., 1968; Birch et al., 1968; Lachenbruch, 1970), which has given rise to the concept of heat flow provinces and helped to explain some of the regional variation in continental heat flow in terms of upper crustal heterogeneity. The purpose of the present paper is to investigate whether 
continental heat flow data sets can yield significant additional information beyond these firstorder generalizations. Do regional heat flow data sets, along with ancillary geophysical and geochemical data, provide sufficient constraints to address variations on the first-order themes dcscribed above?

We address that question by focusing on east and southern Africa because there heat flow measurements define a common first-order heat flow pattern but also show clear regional variability. The first-order heat flow pattern suggests that the gross thermal structure of the lithosphere beneath east and southern Africa is similar (Ballard and Pollack, 1987; Nyblade et al., 1990); however, the variations in heat flow superimposed on this common pattern suggest that there may also be some differences in the thermal structure of the lithosphere between these two regions. Specifically, we wish to determine if variations in the heat flow pattern between east and southern Africa can be easily interpreted to show in what ways the thermal structure of the lithosphere may differ between these two regions. We first briefly describe the first-order heat flow pattern in east and southern Africa on which the regional variability is superimposed, and review our interpretation of this first-order pattern.

\section{First-order heat flow pattern}

The southern African subcontinent is a complex Precambrian terrain that comprises two similar tectonic regions, east and southern Africa.
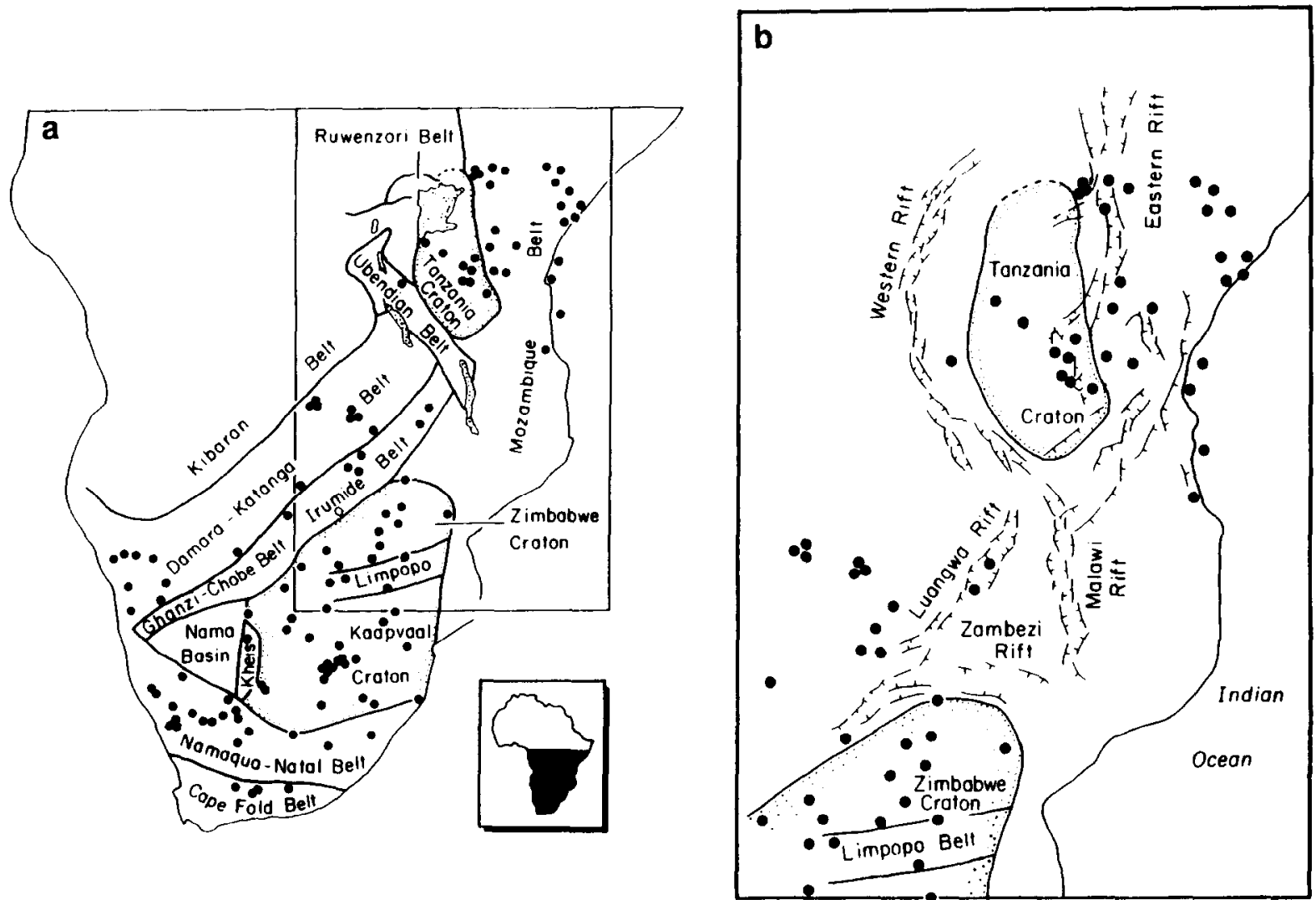

Fig. 1. (a) Map of east and southern Africa showing the locations of heat flow sites (solid circles) in relation to the principal Precambrian tectonic units. The Kalahari Craton is comprised of the Zimbabwe and Kaapvaal Cratons sutured by the Archean Limpopo Belt. The box shows the area represented in (b). (b) Map of heat flow sites (solid circles) in relation to the major Phanerozoic rift valleys and Archean cratonic nuclei. 
The geology of these regions is characterized largely by Archean cratonic nuclei (the Tanzania Craton in east Africa and the Kalahari Craton in southern Africa) surrounded by Proterozoic mobile belts. During the Phanerozoic the mobile beits in both regions were fractured by several episodes of rifting. Figure 1 shows the location of heat flow sites in east and southern Africa in their tectonic setting. Heat flow measurements have been made in all the major Precambrian terrains in southern Africa, except the Mozambique Belt to the northeast of the Kalahari Craton. In east Africa heat flow measurements are principally from the Tanzania Craton and Mozambique Belt. Measurements from the rift valleys were made in the Luangwa, Zambezi and Eastern (Kenya) rifts, and additionally there are some measurements from the Mesozoic extensional sedimentary basins along the east African coast. Detailed descriptions of many of the heat flow measurements can be found in Nyblade et al. (1990), along with references to measurements made by other investigators.

The first-order regional heat flow pattern common to both east and southern Africa is shown in Figure $2 a$ and $b$, where heat flow is plotted as a function of distance from the margin of the respective Archean cratons. The pattern is characterized by low heat flow in the interiors of the cratons and higher heat flow in the surrounding mobile belts. In southern Africa, heat flow in the center of the Kalahari craton is about 40 $\mathrm{mW} \mathrm{m^{-2 }}$ and increases to around $65 \mathrm{~mW} \mathrm{~m}^{-2}$ on average in the mobile belts (Ballard et al., 1987; Nyblade et al., 1990). In east Africa, heat flow in the Tanzania Craton is $34 \mathrm{~mW} \mathrm{~m}^{-2}$ on average and increases to about $60-70 \mathrm{~mW} \mathrm{~m}^{-2}$ in the mobile belts (Nyblade et al., 1990).

The common heat flow pattern clearly suggests that the gross thermal structure of the lithosphere in east and southern Africa is similar. Nyblade and Pollack (1993) and Ballard and Pollack (1987) argued that this heat flow pattern is attributable to much thicker $(\geqslant 100 \mathrm{~km}$ ) lithosphere beneath the Archean cratons than beneath the mobile belts. They showed with thermal models that thick cratonic lithosphere impedes the flow of mantle heat to the surface and
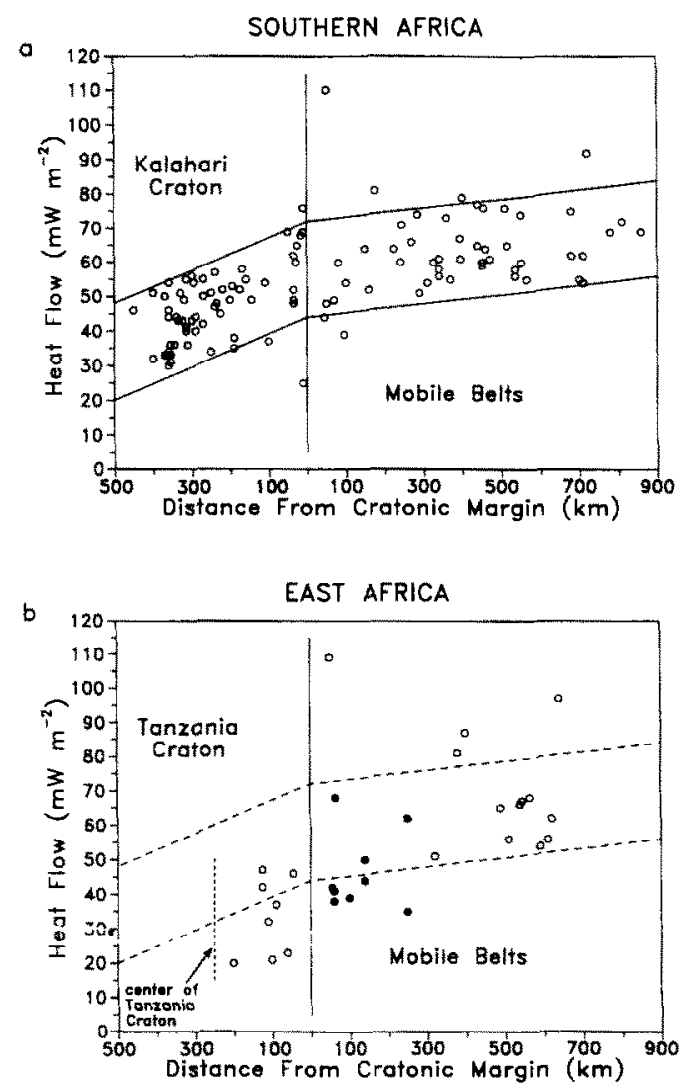

Fig. 2, (a) Heat flow vs. distance from the Kalahari Craton margin. The parallel lines encompass $92 \%$ of the data and serve only to highlight the general trend of increasing heat flow away from the cratonic center. (b) Heat flow versus distance from the Tanzania Craton margin. The solid circles are heat flow measurements from the Mozambique Belt within $250 \mathrm{~km}$ of the Tanzania Craton Margin. Measurements from Cenozoic rift valleys are not shown. The dashed parallel lines are the same as the solid parallel lines in (a) and serve as a visual reference.

requires more mantle heat to escape through adjacent thinner mobile belt lithosphere. Thus, surface heat flow is diminished in areas with thicker lithosphere (cratons) and augmented in areas with thinner lithosphere (mobile belts).

\section{Regional variability in heat flow between east and southern Africa}

In addition to the first-order regional heat flow trend, the regional differences in heat flow between east and southern Africa are also apparent in Figure 2. By comparing heat flow between 
the Tanzania and Kalahari Cratons, as well as between the mobile belts in east and southern Africa it is clear that (1) heat flow in the Tanzania Craton $\left(34 \pm 4(\mathrm{sem}) \mathrm{mW} \mathrm{m}^{-2}\right)$ is lower than in the Kalahari Craton $\left(47 \pm 2(\mathrm{sem}) \mathrm{mW} \mathrm{m}^{-2}\right)$ by about $13 \mathrm{~mW} \mathrm{~m} \mathrm{~m}^{-2}$, and (2) heat flow in the Mozambique Belt within $250 \mathrm{~km}$ of the Tanzania Craton $\left(47 \pm 4(\mathrm{sem}) \mathrm{mW} \mathrm{m} \mathrm{m}^{-2}\right)$ is about 9 $\mathrm{mW} \mathrm{m} \mathrm{m}^{-2}$ lower than heat flow in the southern African mobile belts within $250 \mathrm{~km}$ of the Kalahari Craton $\left(56 \pm 4(\mathrm{sem}) \mathrm{mW} \mathrm{m}^{-2}\right)$.

To determine whether or not we can resolve the variations in the thermal structure of the lithosphere associated with these regional heat flow differences, in the following sections we propose four explanations for the heat flow differences and examine each one to determine which, if any, can reasonably account for the observations. Three of the four explanations can be attributed either to variations in crustal heat production or to variations in mantle heat flow. The diagrams in Figure 3 illustrate these three explanations and will serve as a "flow chart" for this study; each will be discussed in turn as we examine the explanations.

\section{Diminished heat flow in shallow boreholes in east Africa}

The first explanation that we examine, not illustrated in Figure 3, is that low heat flow in the Tanzania Craton and Mozambique Belt, determined from relatively shallow boreholes, is unrepresentative of the regional heat flow and therefore the average of the measured heat flows is shifted downward. For example, it has been noted that the average heat flow in boreholes less than $150 \mathrm{~m}$ deep in the Tanzania Craton is $24 \pm 3$ (sem) $\mathrm{mW} \mathrm{m}^{-2}$, in contrast to an average of $43 \pm 2(\mathrm{sem}) \mathrm{mW} \mathrm{m}^{-2}$ in the deeper boreholes from the craton (Nyblade et al., 1990). These data could be interpreted as suggesting that heat flow determined in the shallower boreholes is diminished from regional values, and that heat flow from the Tanzania Craton would not be significantly different from the Kalahari Craton, if all measurements in the Tanzania Craton were from deep boreholes. a

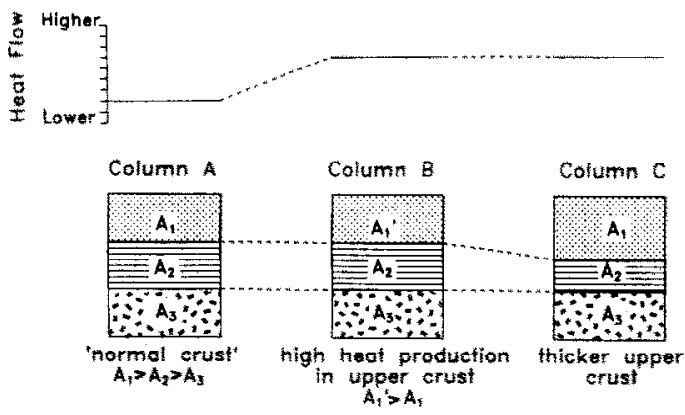

b
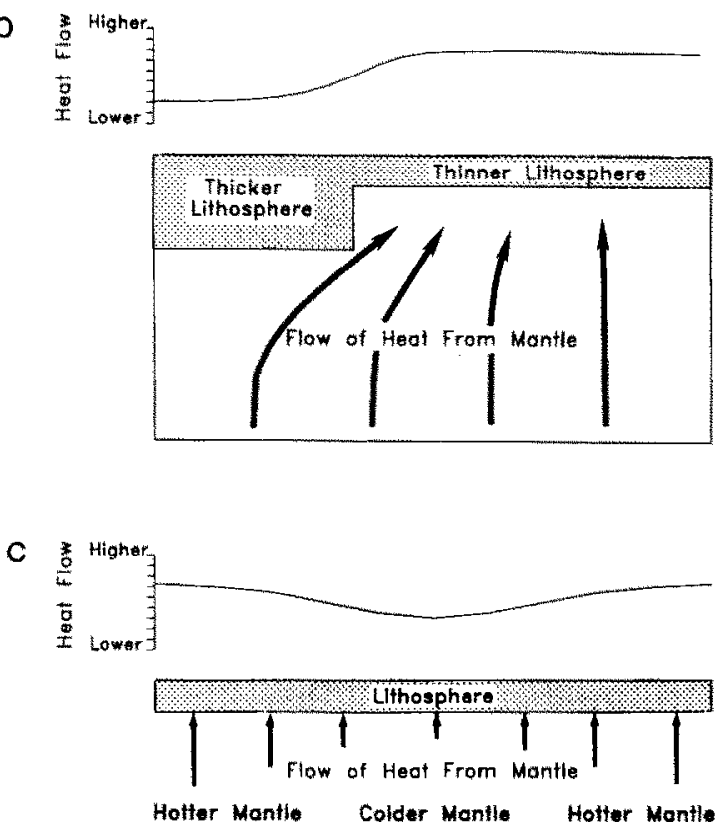

Fig. 3. Diagrams illustrating explanations for heat flow differences between east and southern Africa. (a) Variations in crustal heat production. The columns show how the depth distribution of crustal heat production may vary and the effect on surface heat flow, Column $A=$ "normal" crustal heat source distribution; Column $B=$ enriched upper crust; Column $C=$ thicker upper crust. $A_{1}, A_{2}$, and $A_{3}$ are heat production in the upper, middle and lower crust, respectively. (b) Thicker lithosphere beneath regions of lower heat flow. Mantle heat flow is diverted from beneath regions of thicker lithosphere to regions of thinner lithosphere. (c) Cooler sublithospheric mantle temperatures (and lower mantle beat flow) beneath regions of lower surface heat flow.

Groundwater movement and surface temperature changes are obvious candidates that could cause a lower heat flow in shallower boreholes by lowering near-surface temperature gradients. However, we find little evidence for either groundwater movement or surface temperature 
changes in the borehole temperature measurements; temperature gradients in shallow boreholes do not show the characteristic curvature indicative of groundwater flow or surface temperature changes. Furthermore, heat flow in the deeper boreholes from the Tanzania Craton does not show an increase with depth, nor do the sliallower boreholes in the Mozambique Belt yield systematically lower heat flow than deeper boreholes, as in the Tanzania Craton. In the absence of persuasive evidence that near-surface temperature gradients are perturbed at measurement sites with shallower boreholes, we reject this explanation.

\section{Crustal heat production}

Variations in the total amount of heat generated in the crust between the Tanzania and Kalahari Cratons, and also between the Mozambique Belt and the southern African mobile belts, would provide a simple explanation for the regional heat flow differences. Heat produced in the crust comes primarily from the decay of unstable $\mathrm{U}, \mathrm{Th}$ and $\mathrm{K}$ isotopes. To calculate the total amount of heat generated in the crust, estimates are required of how heat production is distributed in the crust with depth. The distribution of heat production with depth in the continental crust has been the focus of considerable discussion in the literature. Figure 3a illustrates two ways in which the depth distribution of crustal heat production can vary: (1) the concentration of heat producing isotopes in a crustal unit can differ (Fig. 3a, Column B), or (2) there can be differences in the thickness of crustal units (Fig. 3a, Column $C$ ).

In this section we attempt to estimate the depth distribution of crustal heat production in the cratons and mobile belts in east and southern Africa in order to ascertain if there are variations in the total crustal heat production between these regions. Below, we briefly discuss four common approaches used to estimate the depth distribution of crustal heat production, and then try to usc the approaches to estimate the depth distribution of crustal heat production in the cratons and mobile belts.
Approaches to estimating the depth distribution of crustal heat production

Estimates from the linear heat flow-heat production relationship

This approach uses the empirical linear heat flow-heat production relationship observed in many regions around the world (e.g., Roy et al., 1968; Lachenbruch, 1970; Vitorello and Pollack, 1980). In this approach, heat transfer is assumed to be essentially one-dimensional, the slope of the heat flow-heat production regression line is interpreted as the characteristic vertical scale length of the heat source distribution in the upper crust, and the intercept of the regression line is taken as the heat flux into the base of this zone.

For the past two decades this approach has been widely used, but the physical and geological significance of the linear heat flow-heat production relationship is currently the subject of debate. In particular, interpretations using a one-dimensional model (described above) have been questioned by several investigators (England et al., 1980; Jaupart, 1983; Vasseur and Singh, 1986; Nielsen, 1987; Fountain et al., 1987; Furlong and Chapman, 1987), who show that two- and threedimensional heat transfer can also give rise to an apparent linear heat flow-heat production relationship under certain circumstances, depending on correlation scales of crustal heterogeneities. Moreover, Nielsen (1987) and Furlong and Chapman (1987) showed that the slope and intercept of the regression line depends not only on the horizontal and vertical scales of heterogeneity in crustal heat production, but also on the correlation between crustal heat production and thermal conductivity. Nielsen (1987) further suggested that the ratio of heat production within the upper crustal layer to heat flow from beneath this layer influences the slope and intercept of the regression line as well. Where lateral and vertical heterogeneity exists in the crust, the linear heat flow-heat production relationship may not necessarily yield a characteristic scale length of the heat production distribution, and therefore the use of heat flow and heat production data to 
estimate the depth distribution of crustal heat production becomes much more complex.

\section{Estimates from heat production-seismic velocity relationships}

A second approach to estimating the depth distribution of crustal heat production uses an empirical relationship between seismic $\mathrm{P}$-wave velocity $\left(V_{\mathrm{p}}\right)$ and heat production $A$ (Rybach, 1976, 1978/79; Allis, 1979; Rybach and Buntebarth, 1982). The relationship has the general form In $A=\gamma-\beta V_{\mathrm{p}}$, where $\gamma$ and $\beta$ are constants determined from a regression of $A$ and $\mathrm{V}_{\mathrm{P}}$ data. Many different $A-V_{\mathrm{P}}$ curves have been published, each based on measurements from different geological terrains (Rybach and Buntebarth, 1984; Gordienko and Pavlenkova, 1985; Stegena and Meissner, 1985; Cermak and Rybach, 1989; Cermak and Bodri, 1991).

While this approach may hold some promise for constraining the distribution of heat production within the crust, published $A-V_{\mathrm{P}}$ curves must be used with caution. In a general way there appears to be a correlation between $A$ and $V_{\mathrm{P}}$ for many rock types, but this empirical relationship is not well determined or understood. For example, data used by Rybach and Buntebarth (1982) to construct their $A-V_{\mathrm{P}}$ curve show a much better correlation between $A$ and $V_{\mathrm{P}}$ for some rock types (granites, tonalites, amphibolites and pyroxenites) than for others (gabbros and serpentinites), suggesting that a correlation between $A$ and $V_{\mathrm{p}}$ may exist for some rock types but not for others. The large variety of $A-V_{\mathrm{p}}$ curves published for different geologic terrains yield heat production estimates that can vary by a factor of two or more for a given $V_{\mathrm{P}}$ value, indicating that the $A-V_{\mathrm{P}}$ relationship is not tightly constrained. Additionally, it has been shown that there is no clear correlation between $A$ and $V_{\mathrm{P}}$ measurements for typical crustal rocks from some regions (Fountain, 1986; Kern and Siegesmund, 1989; but also see Cermak et al., 1990). There appears to be sufficient ambiguity and uncertainty surrounding the $A-V_{\mathrm{p}}$ relationship to make first-order estimates of the depth distribution of crustal heat production using pub- lished $A-V_{\mathrm{P}}$ curves less than robust, and second-order variability unresolvable.

\section{Estimates from crustal structure}

Seismic velocity data can be used in a more general way to constrain the depth distribution of crustal heat production. Seismic velocity data are commonly used to model crustal structure, and variations in crustal structure between regions can be used to infer, in a broad way, variations in the depth distribution of crustal heat production (Fig. 3a, Column $C$ ). The upper crust typically has higher heat production than the middle crust, which in turn probably has higher heat production than the lower crust. If the thickness of crustal units (c.g., upper crust vs. lower crust) varies between regions, as determined from seismic velocities, then by assigning average heat production values to the crustal units, it is possible to estimate the depth distribution of crustal heat production and to calculate the total crustal heat production. This approach varies from the previous one in that seismic velocities are used only to identify crustal units and the heat production values assigned to the crustal units are not determined by an empirical $A-V_{\mathrm{P}}$ relationship.

\section{Estimates from lithologies}

The fourth approach to estimating the depth distribution of crustal heat production uses heat production measurements from various crustal rocks along with estimates of abundances of these rock types in the crust. These include outcrop samples believed to be typical of upper, middle and lower crustal rocks, crustal xenoliths, rocks exposed in crustal cross-sections, and sedimentary rocks derived from crystalline crustal rocks (e.g., Wilson, 1978; lyer et al., 1984; Taylor and McLennan, 1985; Ashwal et al., 1987; Fountain et al., 1987). Crustal heat production data obtained from these sources provide important constraints on the depth distribution of crustal heat production for specific areas and facilitate the construction of local crustal heat production models. It is difficult, however, to extrapolate these data to other areas because of the great heterogeneity of the continental crust (Kay and Kay, 1986; Foun- 
tain and Christensen, 1989), and the wide range in heat production found not only between crustal rocks of different lithologies, but also between rocks of similar composition. For instance, Fountain et al. (1987) reported heat production values ranging from $0.44 \mu \mathrm{W} \mathrm{m} \mathrm{m}^{-3}$ to $3.76 \mu \mathrm{W} \mathrm{m} \mathrm{m}^{-3}$ for trondhjemite gneisses from the Pikwitonei Subprovince in Manitoba, and Ashwal et al. (1987) reported heat production values from 0.20 $\mu \mathrm{W} \mathrm{m} \mathrm{m}^{-3}$ to $6.89 \mu \mathrm{W} \mathrm{m} \mathrm{m}^{-3}$ for tonalite gneisses from the Kapuskasing uplift in Ontario, Canada. Without detailed constraints on local crustal structure and petrology, constructing local heat production models using data obtained from other regions is problematic and will result in large uncertainties for estimates of the local depth distribution of crustal heat production.

Estimating the depth distribution of crustal heat production in east and southern Africa

Despite the limitations of these approaches, can they be used to constrain the depth distribution of crustal heat production in both east and southern African cratons and mobile belts and thus enable regional comparisons? Because there is significantly less pertinent information from east Africa than southern Africa, our ability to compare crustal heat production between east and southern Africa is limited by the heat production, seismic, and petrologic data available for the Tanzania Craton and Mozambique Belt. Unfortunately, as we show below, there are insufficient data from the Tanzania Craton to make use of any of the approaches, and for the Mozambique Belt, only two of the approaches can be used,

Estimates from the linear heat-flow heat production relationship

Heat flow-heat production data from east and southern Africa are shown in Figure 4 and have been discussed in detail by Nyblade et al. (1990). There are only five heat production measurements on surficial rocks from the Tanzania Craton and only two from the Mozambique Belt. These few data are insufficient to demonstrate whether or not there is a linear correlation between heat flow and heat production in these east African terrains.

Heat production measurements can also give an indication of similarities or differences in surface heat production. Although there are only a few heat production measurements from east Africa, they generally fall within the range of measurements from southern Africa and weakly suggest that at the surface heat production in the Tanzania and Kalahari Cratons is similar, as well as in the Mozambique Belt and southern African mobile belts. However, even though the heat production measurements may suggest that surface heat production does not differ between the Tan-
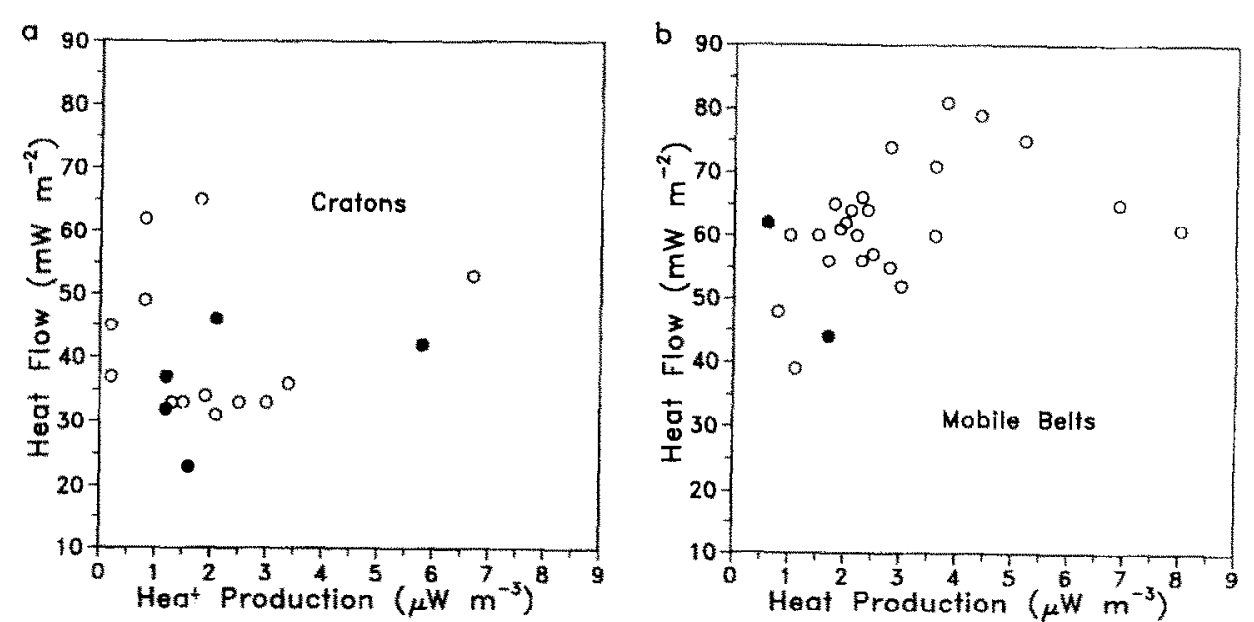

Fig. 4. Heat flow vs. heat production. (a) Data from the Kalahari Craton (open circles) and the Tanzania Craton (solid circles). (b) Data from the southern African mobile belts (open circles) and Mozambique Belt in east Africa (solid circles). 
zania and Kalahari Cratons or between the Mozambique Belt and the southern African mobile belts, they provide little information about how crustal heat production at depth may differ between east and southern Africa vis-a-vis the linear heat flow-heat production relationship.

\section{Estimates from heat production-seismic velocity relationships}

Crustal velocity models for the Namaqua (Green and Durrheim, 1990) and Damara Belts (Baier et al., 1983) in southern Africa and for the Mozambique Belt (KRISP working party, 1991) in east Africa can be used to constrain crustal heat production in the east and southern African mobile belts via an $A-V_{\mathrm{P}}$ relationship. Using the $A-V_{\mathrm{P}}$ relationship from Cermak and Rybach (1989) to convert velocities to heat production yields a crustal column with a surface heat flow of about $35 \mathrm{~mW} \mathrm{~m}^{-2}$ for the Namaqua Belt, 37 $\mathrm{mW} \mathrm{m} \mathrm{m}^{-2}$ for the Damara Belt, and $34 \mathrm{~mW} \mathrm{~m}^{-2}$ for the Mozambique Belt away from the Kenya Rift Vallcy. The uncertaintics in these estimates are probably $\pm 40 \%$ or more; however, in spite of these large uncertainties, the similarity in seismic structure, and thus in the estimated total crustal heat production between these mobile belts suggests that the difference in heat flow between the Mozambique Belt and the southern African mobile belts may not arise from gross variations in crustal heat production. There are no seismic velocity data for the Tanzania Craton and so an $A-V_{\mathrm{P}}$ relationship cannot be used to estimate differences in crustal heat production between the Tanzania and Kalahari Cratons.

\section{Estimates from crustal structure}

Comparing the crustal velocity models for the Namaqua, Damara, and Mozambique Belts cited above, also shows that the thickncss of intracrustal layers in the three mobile belts is roughly the same, further suggesting that crustal heat production does not differ considerably between the mobile belts in east and southern Africa. For the cratons, crustal thickness estimates in the Kalahari Craton are between 35 and $40 \mathrm{~km}$ (Gane et al., 1956; Stuart and Zengeni, 1987) but, as mentioned previously, there are no seismic obser- vations of crustal structure for the Tanzania Craton. Given the uniformity of crustal thickness in Archean cratons worldwide (Durrheim and Mooney, 1991), it is not unreasonable to assume that the Tanzania Craton crust does not depart significantly from the thickness of the Kalahari Craton crust. However, the lack of data from the Tanzania Craton precludes any further discussion of differences in intra-crustal structure between the Tanzania and Kalahari Cratons.

\section{Estimates from lithologies}

In regard to constructing local models of crustal heat production from representative rock samples, there are no heat production estimates for xenoliths or sedimentary rocks from east Africa that could be used to constrain the depth distribution of crustal heat production in the Tanzania Craton or Mozambique Belt, nor are there any reported crustal cross-sections.

\section{Summary of crustal heat production}

In summary, similar crustal velocity models for the Mozambique Belt and two southern African mobile belts suggest that there is no difference in the total crustal heat production between the east and southern African mobile belts. However, because corroborative evidence from surface heat production and petrologic information is lacking, it is not easy to make a robust case that differences in crustal heat production between the east and southern African mobile belts do not give rise to the differences in heat flow. There is insufficient data of any kind to estimate the depth distribution of crustal heat production in the Tanzania Craton, and therefore no conclusion can be reached about variations in crustal heat production between the Kalahari and Tanzania Cratons.

\section{Mantle heat flow}

In this section we examine the possibility that the lower surface heat flow in some areas of east Africa relative to southern Africa may be due to lower mantle heat flow into the base of the lithosphere. There are at least two possible explana- 
tions why mantle heat flow could be lower beneath the Tanzania Craton and Mozambique Belt in east Africa compared to the Kalahari Craton and southern African mobile belts, respectively: (1) the lithosphere in east Africa could be thicker (Fig. 3b), or (2) sub-lithospheric mantle temperatures could be lower (Fig. 3c).

\section{Thicker lithosphere beneath the Tanzania Craton and Mozambique Belt}

As discussed above, and illustrated in Figure $3 \mathrm{~b}$, thick lithosphere diverts the vertical flow of mantle heat, and therefore surface heat flow is diminished in areas of thicker lithosphere relative to areas of thinner lithosphere. Assuming that the spatially averaged mantle heat flux is the same beneath east and southern Africa, can thicker lithosphere beneath the Mozambique Belt with respect to the southern African mobile belts and beneath the Tanzania Craton with respect to the Kalahari Craton explain the heat flow observations?

To address this question, we calculate surface heat flow for models shown in Figure $5 a$ and $c$. The modeling approach we use is described by Nyblade and Pollack (1993), where the lithosphere is treated as a rigid, conductive lid and heat transfer in the convecting mantle is calculated using an algorithm for full thermal convection. The gcometries of the models follow from the interpretation of the regional heat flow pattern in east and southern Africa discussed in the first section, where the contrast in heat flow
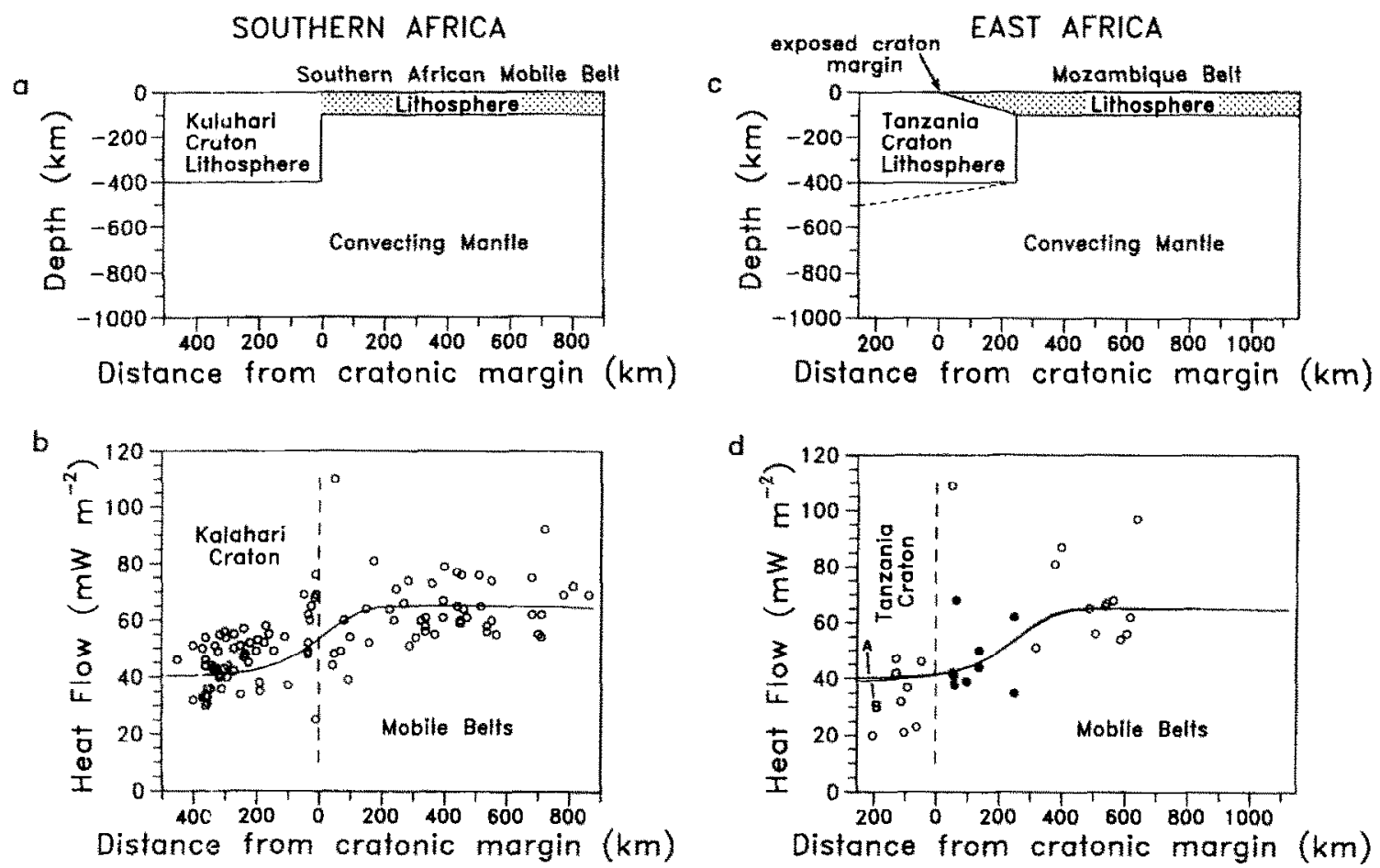

Fig. 5. Thermal models for east and southern Africa. (a) Model geometry for southern Africa after Ballard and Pollack (1987) and Nyblade and Pollack (1991). (b) Heat flow measurements (circles) and modeled heat flow (curved line) for southern Africa vs. distance from the craton margin. (c) Model geometries for east Africa. In the initial model, the lithosphere beneath the Tanzania Craton is $400 \mathrm{~km}$ thick (solid line at the base of the craton). In the second model, the base of the lithosphere is $500 \mathrm{~km}$ thick in the center of the craton and decreases to a thickness of $400 \mathrm{~km}$ at the craton margin (dashed line at the base of the craton). The geometry of the Mozambique Belt is the same in both models; Mozambique Belt rocks overlay $250 \mathrm{~km}$ (horizontally) of the craton, putting thick cratonic lithosphere under the Mozambique Belt rocks nearest to the exposed craton margin. (d) Heat flow measurements (circles) and modeled heat flow (curved lines) vs. distance from the craton margin. The solid circles are heat flow measurements from the Mozambique Belt within $250 \mathrm{~km}$ of the surficial craton margin. Curve $A$ is for the model with a craton of uniform thickness ( $400 \mathrm{~km}$ ), and curve $B$ is for the model with a craton having a tapered base. 
TABLE 1

Thermal and rheological properties for models in Figure 5

\begin{tabular}{ll}
\hline Property & Value \\
\hline Coefficient of thermal expansion & $3.0 \times 10^{-5} \mathrm{~K}^{-1}$ \\
Gravitational acceleration & $9.8 \mathrm{~m} \mathrm{~s}^{-2}$ \\
Thermal conductivity & $3 \mathrm{~W} \mathrm{~m} \mathbf{K}^{-1} \mathrm{~K}^{-1}$ \\
Thermal diffusivity & $1.0 \times 10^{-6} \mathrm{~m}^{2} \mathrm{~s}^{-1}$ \\
Kinematic viscosity & $3.0 \times 10^{17} \mathrm{~m}^{2} \mathrm{~s}^{-1}$ \\
Rayleigh number & $8.0 \times 10^{6}$ \\
$\begin{array}{l}\text { Crustal thickness (constant across } \\
\quad \text { cratons and mobile belts) }\end{array}$ & $40 \mathrm{~km}$ \\
$\begin{array}{l}\text { Crustal heat production } \\
\text { Lithospheric mantle heat production }\end{array}$ & $6.0 \times 10^{-7} \mathrm{~W} \mathrm{~m}^{-3}$ \\
Sub-lithospheric mantle heat production & $4.0 \times 10^{-8} \mathrm{~W} \mathrm{~m}^{-3}$ \\
\hline
\end{tabular}

between the cratons and mobile beits is attributed to much thicker lithosphere under the cratons than under the mobile belts. The models are two-dimensional with the craton in the center, far from the edges of the model to ensure that edge effects do not perturb the thermal regime within it. As the models are symmetric about their mid-points, we display only the right side of each model. The thermal and rheological properties used in the models are given in Table 1.

The model results are shown in Figure $5 b$ and $\mathrm{d}$, where heat flow measurements and modeled heat flow are plotted as a function of the distance from the cratonic margin. The modeled heat flow in the Kalahari Craton is about $40 \mathrm{~mW} \mathrm{~m}^{-2}$, similar to observed heat flow in the interior of the Kalahari Craton and somewhat lower than the mean cratonic value of $47 \mathrm{~mW} \mathrm{~m}^{-2}$ (Fig. 5b). In the southern African mobile belts the modeled heat flow is about $65 \mathrm{~mW} \mathrm{~m}^{-2}$, similar to the mean observed value from the southern African mobile belts (Fig. 5b). In the Tanzania Craton the modeled heat flow is somewhat higher than the mean cratonic value, but in the Mozambique Belt within $250 \mathrm{~km}$ of the craton margin the modeled heat flow is in good agreement with the heat flow observations (Fig. 5d).

The results show that it is difficult to explain the lower heat flow in the Tanzania Craton by thickening the cratonic lithosphere. Increasing the thickness from 400 to $500 \mathrm{~km}$ (Fig. 5c) lowers heat flow from the Tanzania Craton by only about
$1 \mathrm{~mW} \mathrm{~m} \mathrm{~m}^{-2}$ (Fig. 5d), well short of the difference between heat flow in the Kalahari and Tanzania Cratons. Hence, thicker lithosphere beneath the Tanzania Craton (as compared to the Kalahari Craton) does not appear to be a reasonable explanation for the lower heat flow in the Tanzania Craton with respect to the Kalahari Craton. Even if the thickness of the Tanzania Craton exceeded $500 \mathrm{~km}$, it would still be difficult to obtain a $13 \mathrm{~mW} \mathrm{~m}^{-2}$ difference in heat flow between the Tanzania and Kalahari Cratons from this effect.

The lithosphere beneath the Kalahari Craton in the models is $400 \mathrm{~km}$ thick. However, minimum estimates of about $200 \mathrm{~km}$ for the thickness of the Kalahari Craton lithosphere are given by thermobarometry data from diamond inclusions (Richardson et al., 1984) and seismic models (Clouser and Langston, 1990). If 200-km-thick lithosphere is a minimum thickness for the Kalahari Craton lithosphere, can a difference in lithospheric thickness of between $200 \mathrm{~km}$ beneath the Kalahari Craton and 400 or $500 \mathrm{~km}$ beneath the Tanzania Craton produce the $13 \mathrm{~mW} \mathrm{~m}^{-2}$ difference in heat flow observed between the Kalahari and Tanzania Cratons? Our thermal models show that it is not likely. Surface heat flow diminishes approximately exponentially as the lithosphere thickens, and so thickening already thick (200 $\mathrm{km}$ ) lithosphere, even by an additional 200 to 300 $\mathrm{km}$, reduces surface heat flow by only 5-6 $\mathrm{mW} \mathrm{m} \mathrm{m}^{-2}$.

On the other hand, the models suggest that the lower heat flow in the Mozambique Belt can be explained by thicker lithosphere relative to that beneath the southern African mobile belts. Placing 400-km-thick lithosphere beneath the Mozambique Belt within $250 \mathrm{~km}$ of the surficial craton margin diminishes surface heat flow sufficiently to account for the lower heat flow. With such a structure, the average modeled heat flow in the Mozambique Belt within $250 \mathrm{~km}$ of the Tanzania Craton is $47 \mathrm{~mW} \mathrm{~m} \mathrm{~m}^{-2}$, similar to the average observed heat flow (Fig. 5d).

Is there other geological or geophysical evidence for thicker lithosphere beneath the Tanzania Craton and Mozambique Belt compared to the Kalahari Craton and southern African mobile belts? For the Tanzania Craton there is none, but 
for the Mozambique Belt there is some. Recent geological studies of the Mozambique Belt in Tanzania and Kenya interpret this mobile belt as a continent-continent collision zone (Shackleton, 1986; Key et al., 1989). Structural evidence indicates that Mozambique Belt rocks are thrust to the west, and therefore the eastern boundary of the Tanzania Craton at depth may lie to the east of the heat flow sites in the Mozambique Belt. If this interpretation is correct, then the lithosphere beneath the Mozambique Belt may be thicker than beneath the southern African mobile belts because the Mozambique Belt is underlain by cratonic lithosphere, as shown in Figure 5c.

However, it is possible that some of the southern African mobile belts may be underlain by thick cratonic lithosphere as well. If so, then to account for the lower heat flow in the Mozambique Belt in east Africa relative to the southern African mobile belts, the cratonic lithosphere beneath the Mozambique Belt must be thicker than that beneath the southern African mobile belts.

In the light of our thermal models and the geological evidence for westward thrusting of Mozambique Belt rocks onto the margin of the Tanzania Craton, thickened lithosphere beneath the western edge of the Mozambique Belt relative to the southern African mobile belts is a possible explanation for the lower surface heat flow in this mobile belt in comparison to heat flow in the southern African mobile belts. The same cannot be said for the lower heat flow in the Tanzania Craton; additional thickening of the craton lithosphere will not likely diminish heat flow by a sufficient amount to explain the difference in heat flow between the Kalahari and Tanzania Cratons.

\section{Lower mantle temperatures beneath east Africa}

Numerical and analytical studies of mantle convection suggest that the base of the lithosphere can experience temperature variations (spatial and temporal) on the order of a few hundred degrees, accompanied by corresponding variations in mantle heat flux. Such temperature variations are usually related to mantle upwellings and downwellings. If mantle tempera- tures are lower beneath east Africa than beneath southern Africa, then the heat flux from the mantle into the base of the east African lithosphere must be smaller, and if the basal temperature anomaly is of sufficient magnitude and persists for an adequate length of time, surface heat flow will diminish (Fig. 3c).

To examine if lower mantle temperatures (and heat flow) can reasonably account for the lower heat flow in the Tanzania Craton and Mozambique Belt, we have calculated the time-dependent behavior of surface heal flow that results from an instantaneous change in temperature at the base of a slab. The transient response of surface heat flow for a sudden change in temperature at the base of a slab is given by:

$q=k \Delta T / h\left\{1+2 \sum_{n=1}^{\infty}(-1)^{n} \exp \left(-n^{2} \pi^{2} \kappa t / h^{2}\right)\right\}$

where $q$ is heat flow, $\Delta T$ is the temperature change at the base of the slab, $h$ is the slab thickness, $k$ is thermal diffusivity, $k$ is thermal conductivity, and $t$ is time since the temperature change occurred (Carslaw and Jaeger, 1959, p. 99). The solution for $\Delta T=300 \mathrm{~K}$ is shown in Figure 6 for various slab thickness and time intervals.

If $\Delta T=300 \mathrm{~K}$ represents a reasonable upper limit to the size of the temperature perturbation (McKenzie et al., 1974; Gurnis, 1988; Gurnis and Zhong, 1991; Schilling, 1991), the results in Figure 6 show that for cratonic lithosphere between 200 and $400 \mathrm{~km}$ thick, a temperature decrease of $300 \mathrm{~K}$ will lower surface heat flow by less than 1 $\mathrm{mW} \mathrm{m}^{-2}$ over $100 \mathrm{Ma}$ and less than a few $\mathrm{mW} \mathrm{m} \mathrm{m}^{-2}$ for steady-state conditions. Thus, a "cold spot" in the mantle beneath the Tanzania Craton cannot readily explain the significantly lower surface heat flow in this craton compared to the Kalahari Craton. However, similar considerations for the mobile belts yield more promising results. If the lithosphere beneath the Mozambique Belt in east Africa is about $100 \mathrm{~km}$ thick, then an $8 \mathrm{~mW} \mathrm{~m}^{-2}$ reduction in surface heat flow can be achieved after $100 \mathrm{Ma}$, and a reduction of about $9 \mathrm{~mW} \mathrm{~m}^{-2}$ will occur over 300 Ma. Therefore, if lower mantle temperatures be- 


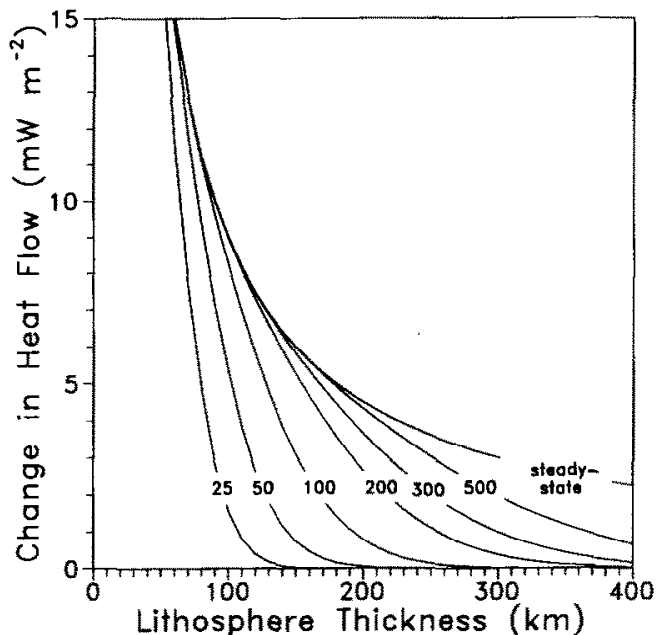

Fig. 6. The change in surface heat flow plotted against lithosphere thickness for a $300 \mathrm{~K}$ step change in temperature at the base of the lithosphere. The numbers on the curves give the time in Ma elapsed since the step change in temperature at the base of the lithosphere occurred. A thermal conductivity of $3 \mathrm{~W} \mathrm{~m}^{-1} \mathrm{~K}^{-1}$ and a thermal diffusivity of $1 \times 10^{-6}$ $\mathrm{m}^{2} \mathbf{s}^{-1}$ were used in this calculation.

ncath the Mozambique Belt have persisted for $100 \mathrm{Ma}$ or longer, heat flow from the mobile belt could be lowered by about $8-9 \mathrm{~mW} \mathrm{~m}^{-2}$, which is about the difference in heat flow observed between the Mozambique Belt and the southern African mobile belts.

Is it likely that upper mantle temperature anomalies associated with mantle convection could have persisted for $100 \mathrm{Ma}$ or longer beneath the Mozambique Belt in east Africa? There is little information about the integrity of mantle heterogeneities over long time intervals that can help answer this question. Anderson (1982) suggested that a large scale lower mantle temperature anomaly beneath the location of the nowfragmented supercontinent Pangea has existed for some $200 \mathrm{Ma}$. Support for this suggestion comes from a region of low seismic velocities in the lower mantle and a positive long wavelength geoid anomaly that correlate with the location of the former supercontinent, suggesting the presence of hotter lower mantle material (Dziewonski, 1984; Hager, 1984; Hager et al., 1985). If lower mantle thermal anomalies can persist for $200 \mathrm{Ma}$, then perhaps upper mantle anomalies can as well. That mantle temperature anomalies have persisted for hundreds of millions of years is clearly not well established, but it is a possibility that cannot be ruled out.

One possible way to lower mantle temperatures beneath the Mozambique Belt is by the diversion of mantlc heat from beneath this region to the thinned and/or rifted lithosphere in east Africa. Just as deep mantle heat is diverted from thick cratonic lithosphere to the surrounding thinner mobile belt lithosphere, so too might mantle heat beneath the Mozambique Belt lithosphere be diverted to the thinned lithosphere beneath the nearby rift valleys. The viability of this interpretation rests on the transport time scales and chronology of the tectonic process.

From Figure 6, the thermal perturbation to the base of the Mozambique Belt lithosphere must have begun at least $100 \mathrm{Ma}$ ago to explain the heat tlow observations. Thus, the diversion of deep mantle heat from beneath the Mozambique Belt to nearby thinned lithosphere must have begun at least $75 \mathrm{Ma}$ before rifting commenced in east Africa at ca. 25 Ma (Baker et al., 1972: Ebinger, 1989). The diversion of deep mantle heat from beneath the Mozambique Belt lithosphere may have begun somewhat prior to the commencement of surface rifting, but it seems unlikely that the thermal perturbation at the base of the mobile belt lithosphere would have begun sufficiently early (100 Ma) as to alter significantly the present-day surface heat flow in the Mozambique Belt.

\section{Summary and conclusions}

Heat flow in the Tanzania Craton is lower than in the Kalahari Craton by about $13 \mathrm{~mW} \mathrm{~m}^{-2}$ and is about $9 \mathrm{~mW} \mathrm{~m}^{-2}$ lower in the Mozambique Belt than in the southern African mobile belts at distances of up to $250 \mathrm{~km}$ from the respective cratonic margins. In an attempt to resolve the differences in the thermal structure of the lithosphere associated with these heat flow variations, we have suggested four possible explanations for the heat flow differences, and have examined each explanation to determine which ones can reasonably account for the heat flow observations. Our results are summarized below. 
(1) Diminished heat flow in shallow boreholes in east Africa

If heat flow measurements from relatively shallow boreholes in the Tanzania Craton and Mozambique Belt are diminished from typical regional values, then this could account for the apparently lower heat flow in east Africa. Groundwater flow and surface temperature changes are obvious candidates that could cause a lower heat flow in shallower boreholes by lowering near-surface temperature gradients. However, there is no evidence to suggest that temperature gradients in shallow boreholes are perturbed by groundwater flow or surface temperature changes, nor does heat flow increase with depth in the deeper boreholes. Therefore we reject this explanation.

\section{(2) Variations in crustal heat production}

It is difficult to demonstrate how much, if any, of the differences in heat flow arise from variations in the total amount of crustal heat production. Petrologic and geophysical data which may provide some constraints on the depth distribution of crustal heat production in the Kalahari Craton are not available for the Tanzania Craton. Similar crustal velocity models of the Mozambique Belt and two southern African mobile belts suggest that there are no significant differences in the total crustal heat production between the east and southern African mobile belts. However, supporting evidence is not available from heat production measurements or petrologic data, and therefore it is not easy to make a robust case that differences in crustal heat production between the east and southern African mobile belts are not the cause of the differences in heat flow. Because $n$ n definitive conclusion can be reached presently regarding variations in crustal heat production between east and southern Africa, variations in crustal heat production must remain a possible explanation for the heat flow observations. Our inability to constrain the depth distribution of crustal heat production reflects the present state of uncertainty about crustal heat production generally.

\section{(3) Thicker lithosphere beneath the Tanzania} Craton and Mozambique Belt

Thermal models suggest that thicker lithosphere beneath the Tanzania Craton cannot account for more than $5-6 \mathrm{~mW} \mathrm{~m}^{-2}$ of the 13 $\mathrm{mW} \mathrm{m}^{-2}$ difference in heat flow between the Tanzania and Kalahari Cratons. Therefore, variations in thickness of cratonic lithosphere seem an unlikely explanation for the heat flow difference between the two cratons. In contrast, geological evidence and results from thermal models indicate that thicker lithosphere beneath the Mozambique Belt is a possible explanation for the lower heat flow in the Mozambique Belt with respect to the southern African mobile belts.

(4) Lower mantle temperatures beneath the Tanzania Craton and Mozambique Belt

A decrease in surface heat flow of $8-9$ $\mathrm{mW} \mathrm{m} \mathrm{m}^{-2}$ from 100-km-thick Mozambique Belt lithosphere can be explained by a $300 \mathrm{~K}$ decrease in temperature at the base of the lithosphere during the last 100 to $300 \mathrm{Ma}$. However, a decrease in sub-lithospheric mantle temperatures of a few hundred degrees beneath $200-400-\mathrm{km}$-thick cratonic lithosphere would not significantly alter surface heat flow, even under steady-state conditions. The possibility that upper mantle temperature anomalies associated with mantle convection persist for hundreds of millions of years cannot be ruled out. That mantle temperatures beneath the Mozambique Belt have been reduced by the diversion of mantle heat to nearby thinned/rifted lithosphere is an unlikely explanation because it would require that the thermal perturbation to the base of the mobile belt lithosphere began about $100 \mathrm{Ma}$ ago, or about $75 \mathrm{Ma}$ before Cenozoic rifting began in east Africa.

In our analysis we have treated each explanation individually. From this perspective, we show that it is difficult to account for the heat flow differences between the Kalahari and Tanzania Cratons with explanations (1), (3) and (4); for the differences in heat flow between the Mozambique Belt and the southern African mobile belts, only explanation (1) can be dismissed as unrea- 
sonable. However, it is possible that the heat flow differences between east and southern Africa could also be accounted for by several of the explanations taken collectively. For example, the lower heat flow in the Tanzania Craton could result in part from some differences in crustal heat production and a somewhat thicker lithosphere. In fact, many combinations of explanations (2), (3) or (4) could account for the observed heat flow variations. Clearly, it is not easy to interpret uniquely the regional heat flow differences between east and southern Africa, and therefore to resolve differences in the thermal structure of the lithosphere between east and southern Africa. Subtle differences in crustal heat production, lithospheric thickness, and mantle temperatures may all contribute to the observed heat flow variations.

Hence, our investigation focusing on east and southern Africa shows that beyond the implications of the first-order pattern of low heat flow in Archean terrains and higher heat flow in the surrounding mobile belts, the extraction of additional information on lithospheric thermal structure from regional heat flow variations requires more ancillary geochemical and geophysical information than Africa presently offers. This study underscores the difficulties in interpreting subtle differences in regional heat flow; the conclusions we reach regarding east and southern Africa suggest that such differences can only be interpreted with confidence in areas having sufficient constraints on crustal heat production, crustal structure, lithospheric thickness, and upper mantle temperatures.

\section{Acknowledgements}

This work has been supported in part by the US National Science Foundation grant EAR8706599. We thank Alan Jessop and David Blackwell for constructive reviews.

\section{References}

Allis, R.G., 1979. A heat production model for stable continental crust. Tectonophysics, 57: 151-165.
Anderson, D.L., 1982. Hotspots, polar wander, Mesozoic convection and the geoid. Nature, 297: 391-393.

Ashwal, L.D., Morgan, P., Kelley, S.A. and Percival, J.A., 1987. Heat production in an Archea with ancilliary geophysical and geochemical data, can yield significant information about lithospheric thermal structure by investigatingn crustal profile and implications for heat flow and mobilization of heat-producing elements. Earth Planet. Sci. Lett., 85: 439-450.

Baier, B., Berckhemer, H., Gajewski, D., Green, R.W., Grimsel, Ch., Prodehl, C. and Vees, R., 1983. Deep seismic sounding in the area of the Damara Orogen, Namibia, South West Africa. In: H. Martin and F.W. Eder (Editors), Intercontinental Fold Belts. Springer, New York, NY, pp. 885-900.

Baker, B.H., Mohr, P.A. and Williams, L.A.J., 1972. The geology of the Eastern Rift System of Africa. Gcol. Soc. Am. Spec. Pap., 136, 67 pp.

Ballard. S. and Pollack, H.N., 1987. Diversion of heat by Archean cratons: a model for southern Africa. Earth Planet. Sci. Lett., 85: 253-264.

Ballard, S., Pollack, H.N. and Skinner, N.J., 1987. Terrestrial heat flow in Botswana and Namibia. J. Geophys. Res., 92: 6291-6300.

Benfield, A.F., 1939. Terrestrial heat flow in Great Britain. Proc. R. Soc. London Ser. A, 173: 428-450.

Birch, F., Roy, R.F. and Decker, E.R., 1968. Ileat flow and thermal history in New York and New England. In: E. Zen, W.S. White, J.B. Hadley and J.B. Thompson Jr. (Editors), Studies of Appalachian Geology: Northern and Maritime. Interscience, New York, NY, pp. 437-451.

Bullard, E.C., 1939. Heat flow in South Africa. Proc. R. Soc. London Ser. A, 173: 474-502.

Carslaw, H.S. and Jaeger, J.C., 1959. Conduction of Heat in Solids. Oxford Univ. Press, New York, NY, 510 pp.

Cermak, V. and Bodri, L., 1991. A heat production model of the crust and upper mantle. Tectonophysics, 194: 307-323.

Cermak, V. and Rybach, L., 1989. Vertical distribution of heat production in the continental crust. Tectonophysics, 159: 217-230.

Cermak, V., Bodri, L., Rybach, L. and Buntebarth, G., 1990. Relationship between scismic velocity and heat production: comparison of two sets of data and test of validity. Earth Planet. Sci. Lett., 99: 48-57.

Chapman, D.S. and Furlong, K.P., 1977. Continental heat flow-age relationships. EOS, Trans. AGU, 58: 1240 (abstr.).

Clouser, R. and Langston, C.A., 1990. Upper mantle structure of southern Africa from $P_{n l}$ waves. J. Geophys. Res., 95: 17,403-17,2415.

Durrheim, R.J. and Mooney, W.D., 1991. Archean and Proterozoic crustal evolution: Evidence from crustal seismology. Geology, 19: 606-609.

Dziewonski, A.M., 1984. Mapping the lower mantle: Determination of lateral heterogeneity in $P$ velocity up to degree and order 6. J. Geophys. Res., 82: 5929-5952.

Ebinger, C.J., 1989. Tectonic development of the western 
branch of the East African rift system. Geol. Soc. Am. Bull., 101: 885-903.

England, P.C., Oxburgh, E.R. and Richardson, S.W., 1980. Heat refraction around granite plutons in north-east England. Geophys. J.R. Astron. Soc., 62: 439-455.

Fountain, D.M., 1986. Is there a relationship between seismic velocity and heat production for crustal rocks? Earth Planet. Sci, Lett., 79: 145-150.

Fountain, D.M. and Christensen, N.1., 1989. Composition of the continental crust and upper mantle; a review. In: L.C. Pakiser and W.D. Mooney (Editors), Geophysical Framework of the Continental United States. Geol. Soc. Am. Mem., 172, pp. 711-742.

Fountain, D.M., Salisbury, M.H. and Furlong, K.P., 1987. Heat production and thermal conductivity of rocks from the Pikwitonei-Sachigo continental cross section, central Manitoba: implications for the thermal structure of Archean crust. Can. J. Earth Sci., 24; 1583-1594.

Furlong, K.P. and Chapman, D.S., 1987. Crustal heterogeneities and the thermal structure of the continental crust. Geophys. Res. Lett., 14: 314-317.

Gane, P.G., Atkins, A.R., Sellschop, J.P.F, and Seligman, P., 1956. Crustal structure in the Transvaal. Bull. Seismol. Soc. Am., 46: 293-316.

Gordienko, V.V. and Pavlenkova, N.I., 1985. Combined geothermal-geophysical models of the earth's crust and upper mantle for the European continent. J. Geodyn., 4: $75-90$.

Green R.W.E. and Durrheim, R.J., 1990. A seismic refraction investigation of the Namaqualand metamorphic complex, South Africa. J. Geophys. Res., 95: 19,927-19,932.

Gurnis, M., 1988. Large-scale mantle convection and the aggregation and dispersal of supercontinents. Nature, 332: 695-699.

Gurnis, M. and Zhong, S., 1991. Generation of long wavelength heterogeneity in the mantle by the dynamic interaction between plates and convection. Geophys. Res. Lett., 18: $581-584$.

Hager, B.H., 1984. Suducted slabs and the geoid: Constraints on mantle rheology and flow. J. Geophys. Res., 89: 60036015.

Hager, B.H., Clayton, R.W., Richards, M.A., Comer, R.P. and Dziewonski, A.M., 1985. Lower mantle heterogeneity, dynamic topography and the geoid. Nature, 313: 541-545.

Iyer, S.S., Choudhuri, A., Vasconcellos, M.B.A. and Cordani, U.G., 1984. Radioactive element distribution in the Archean graulite terrane of Jequie-Bahia, Brazil. Contrib. Mineral. Petrol, 85: 95-101.

Jaupart, C., 1983. Horizontal heat transfer due to radioactivity contrasts: causes and consequences of the linear heat flow relation. Geophys. J.R. Astron. Soc., 75: 411-435.

Kay, R.W. and Kay, S.M., 1986. Petrology and geochemistry of the lower continental crust: an overview. In: J.B. Dawson, D.A. Carswell, J. Hall and K.H. Wedepohl (Editors), The Nature of the Lower Continental Crust. Geol. Soc. London Spec. Publ., 24, pp. 147-159.
Kern, H. and Siegesmund, S., 1989. A test of the relationship between seismic vclocity and heat production for crustal rocks. Earth Planet. Sci. Lett., 92: 89-94.

Key, R.M., Charsley, T.J., Hackman, B.D., Wilkinson, A.F. and Rundle, C.C., 1989. Superimposed upper Proterozoic collision-controlled orogenies in the Mozambique orogenic belt of Kenya. Precambrian Res., 44: 197-225.

Kraskovski, S.A., 1961. On the thermal fields in old shields. Izv, Akad. Nauk. Arm. SSR Geol. Geogr. Nauki., pp. 247-250 (English transl.).

KRISP working party, 1991. The implications of large scale variation in lithospheric structure both along and across the Kenya Rift. Nature, 354: 223-227.

Lachenbruch, A.H., 1970. Crustal temperature and heat production: implications of the linear heat flow relation. $J$. Geophys. Res., 75: 3291-3300.

Lee, W.H.K. and Uyeda, S., 1965. Review of heat now data. In: W.H.K. Lee (Editor), Terrestrial Heat Flow. AGU, Washington, DC, Geophys. Monogr. Ser., 8, pp. 87-190.

McKenzie, D.P., Roberts, J.M. and Weiss, N.O., 1974. Convection in the earth's mantle: Towards a numerical simulation. J. Fluid. Mech., 62: 465-538.

Morgan, $P_{\%}$ 1984. The thermal structure and thermal evolution of the continental lithosphere. Phys. Chem. Earth, 15: $107-193$.

Nielsen, S.B., 1987. Steady state heat flow in a random medium and the linear heat flow-heat production relationship. Geophys. Res. Lett., 14: 318-321.

Nyblade, A.A. and Pollack, H.N., 1993. A comparative study of parameterized and full thermal convection models in the interpretation of heat flow from cratons and mobile belts. Geophys. J. Int., in press.

Nyblade, A.A. and Pollack, H.N., 1993. A global analysis of heat flow from Precambrian terrains: Implications for the thermal structure of Archean and Proterozoic lithosphere. J. Geophys. Res., in press.

Nyblade, A.A., Pollack, H.N., Jones, D.L., Podmore, F. and Mushayandebvu, M., 1990. Terrestrial heat flow in east and southern Africa. J. Geophys. Res., 95: 17,371-17,384.

Pollack, H.N., Hurter, S. and Johnson, J.R., 1990. The new global heat flow data compilation. EOS, Trans. AGU, 71: 1604.

Polyak, B.G. and Smirnov, Y.B., 1968. Relationship between terrestrial heat flow and the tectonics of continents. Geotectonics, 4: 205-213.

Richardson, S.H., Gurney, J.J., Erlank, A.J. and Harris, J.W., 1984. Origin of diamonds in old enriched mantle. Nature, 310: 198-202.

Roy, R.F., Blackwell, D.D. and Birch, F., 1968. Heat generation of plutonic rocks and continental heat flow provinces. Earth Planet. Sci. Lett., 5: 1-12.

Rybach, L., 1976. Radiometric heat production in rocks and its relation to other petrophysical properties. Pure Appl. Geophys., 114: 309-318.

Rybach, L., 1978/1979. The relationship between seismic 
velocity and radioactive heat production in crustal rocks: an exponential law. Pure Appl. Geophys., 117: 75-82.

Rybach, L. and Buntebarth, G., 1982. Relationships between the petrophysical properties density, seismic velocity, heat generation, and mineralogical constitution. Earth Planet. Sci. Lett., 57: 367-376.

Rybach, L. and Buntebarth, G., 1984. The variation of heat generation, density and seismic velocity with rock type in the continental lithosphere. Tectonophysics, 103: 335-344.

Schilling, J.-G., 1991. Fluxes and excess temperatures of mantle plumes inferred from their interaction with migrating mid-ocean ridges. Nature, 352: 397-403.

Sclater, J.G. and Francheteau, J., 1970. The implications of terrestrial heat flow observations on current tectonic and geochemical models of the crust and upper mantle of the earth. Geophys. J.R. Astron. Soc., 20: 509-542.

Sclater, J.G., Jaupart, C. and Galson, D., 1980. The heat flow through oceanic and continental crust and the heat loss of the Earth. Rev. Geophys. Space Phys., 18: 269-311.

Shackleton, R.M., 1986. Precambrian collision tectonics in Africa. In: M.P. Coward and A.C. Ries (Editors), Collision Tectonics. Geol. Soc. London Spec. Publ., 19, pp. 329-349.

Stegena, L. and Meissner, R., 1985. Velocity structure and geothermics of the Earth's crust along the European Geotraverse. Tectonophysics, 121: 87-96.
Stuart, G.W. and Zengeni, T.G., 1987. Seismic crustal structure of the Limpopo mobile belt, Zimbabwc. Tectonophysics, 144: 323-335.

Taylor, S.R, and McLennan, S.M., 1985. The Continental Crust: Its Composition and Evolution. Blackwell, Oxford, $312 \mathrm{pp}$.

Vasseur, G. and Singh, R.N., 1986. The effects of random horizontal variations in the radiogenic heat source distribution and its relationship with heat flow. J. Geophys. Res., 91: 10,397-10,404.

Vitorello, I. and Pollack, H.N., 1980. On the variation of continental heat flow with age and the thermal evolution of continents. J. Geophys. Res., 85: 983-996.

Wilson, A.F., 1978. Comparison of some of the geochemical features and tectonic setting of Archean and Proterozoic granulites with particular reference of Australia. In: B.F. Windley and S.M. Naqvi (Editors), Archean Geochemistry. Elsevier, Amsterdam, pp. 241-267.

Woodhouse, J.H. and Dziewonski, A.M., 1984. Mapping the upper mantle: Three-dimensional modeling of earth structure by inversion of seismic waveforms. J. Geophys. Res., 89: 5953-5986. 